Article

\title{
Proteomics-Based Detection of Immune Dysfunction in an Elite Adventure Athlete Trekking Across the Antarctica
}

\author{
David C. Nieman ${ }^{1, *} \mathbb{0}$, Arnoud J. Groen ${ }^{2}$, Artyom Pugachev ${ }^{2}$, Andrew J. Simonson ${ }^{1}$, \\ Kristine Polley ${ }^{3}$, Karma James ${ }^{3}$, Bassem F. El-Khodor ${ }^{3}$, Saradhadevi Varadharaj ${ }^{3}$ and \\ Claudia Hernández-Armenta ${ }^{2}$ \\ 1 North Carolina Research Campus, Appalachian State University, Kannapolis, NC 28081, USA; \\ simonsonaj@appstate.edu \\ 2 ProteiQ Biosciences GmbH, 10967 Berlin, Germany; arnoud@proteiq.com (A.J.G.); \\ artyom@proteiq.com (A.P.); chernand@ebi.ac.uk (C.H.-A.) \\ 3 Standard Process Nutrition Innovation, Kannapolis, NC 28081, USA; kpolley@standardprocess.com (K.P.); \\ kjames@standardprocess.com (K.J.); belkhodor@standardprocess.com (B.F.E.-K.); \\ svaradharaj@standardprocess.com (S.V.) \\ * Correspondence: niemandc@appstate.edu; Tel.: +1-828-773-0056
}

Received: 11 February 2020; Accepted: 1 March 2020; Published: 3 March 2020

\begin{abstract}
Proteomics monitoring of an elite adventure athlete (age 33 years) was conducted over a 28-week period that culminated in the successful, solo, unassisted, and unsupported two month trek across the Antarctica $(1500 \mathrm{~km})$. Training distress was monitored weekly using a 19-item, validated training distress scale (TDS). Weekly dried blood spot (DBS) specimens were collected via fingerprick blood drops onto standard blood spot cards. DBS proteins were measured with nano-electrospray ionization liquid chromatography tandem mass spectrometry (nanoLC-MS/MS) in data-independent acquisition (DIA) mode, and 712 proteins were identified and quantified. The 28-week period was divided into time segments based on TDS scores, and a contrast analysis between weeks five and eight (low TDS) and between weeks 20 and 23 (high TDS, last month of Antarctica trek) showed that 31 proteins ( $n=20$ immune related) were upregulated and 35 ( $n=17$ immune related) were downregulated. Protein-protein interaction (PPI) networks supported a dichotomous immune response. Gene ontology (GO) biological process terms for the upregulated immune proteins showed an increase in regulation of the immune system process, especially inflammation, complement activation, and leukocyte mediated immunity. At the same time, GO terms for the downregulated immune-related proteins indicated a decrease in several aspects of the overall immune system process including neutrophil degranulation and the antimicrobial humoral response. These proteomics data support a dysfunctional immune response in an elite adventure athlete during a sustained period of mental and physical distress while trekking solo across the Antarctica.
\end{abstract}

Keywords: blood proteins; exercise; immune system; complement; neutrophils; apolipoproteins; nutrition

\section{Introduction}

Successful training leading to enhanced performance involves cycles of overload and adequate recovery [1-4]. A primary goal during training is to avoid the combination of excessive overload and inadequate recovery leading to non-functional overreaching (NFOR) and the overtraining syndrome (OTS) that can result in long term performance decrements and psychological disturbances [1]. 
Practical and sensitive diagnostic tools are needed to identify athletes with NFOR and OTS, but valid blood biomarkers that can be combined with performance and psychological measurements are lacking. There is a growing interest in the use of protein-based biomarkers for NFOR and OTS because protein-protein interactions are specific, information rich, and biochemically diverse $[4,5]$. Technological and bioinformatics advances now allow proteomics analysis to be conducted from dried blood spot (DBS) samples with the identification of specific protein patterns that can be linked to underlying biological processes. The use of DBS samples offers many advantages, especially in athletic and military field settings, including ease and safety of transport, storage, and handling $[4,6]$.

Our research group recently utilized a proteomics approach with DBS samples to identify a cluster of 13 proteins that were expressed during two days of recovery from a three day period of intensive exercise [4]. Protein-protein interactions analysis indicated underlying biological processes related to the acute phase response, complement activation, and innate immune system activation. In a subsequent study, this cluster of 13 proteins successfully identified NFOR in an athlete during the Race Across America (RAAM) [7]. The athlete completed the $4941 \mathrm{~km}$ race in 10.1 days with only $20 \mathrm{~h}$ of sleep, and experienced high psychological training distress and decreased post-race work capacity. Targeted proteomics procedures were conducted on DBS samples that were collected before and after, and twice daily during RAAM, and revealed large fold increases for specific immune-related proteins including complement component C7 (359\%), complement C4b (231\%), serum amyloid A4 protein (210\%), inter-alpha-trypsin inhibitor heavy chain H4 (191\%), and alpha-1-antitrypsin (188\%). These data are consistent with results from multiple human and animal studies showing that immune-related proteins represent a large proportion of those generated during intensive and prolonged acute and chronic exercise training [8-13]. These proteins, when combined with psychological, performance, and nutrition intake data, can serve as useful NFOR and OTS biomarkers of immune dysfunction, training distress, exercise-induced muscle damage and exhaustion, and impaired performance capacity [14-21]. We sought to extend these findings by using proteomics monitoring of an elite adventure athlete over an extended period of time ( 28 weeks) that culminated in the successful solo, unassisted, and unsupported two month trek across Antarctica. The primary purpose of this case history study was to acquire weekly DBS samples and analyze them for shifts in proteins during normal training and overtraining periods to discover additional biomarkers that could be used for NFOR and OTS detection. As in prior studies, participant burden was reduced by using DBS samples collected from fingerprick blood drops. The participant was trained in this technique to allow freedom of travel and improved compliance to the sampling regimen (weekly, Thursday mornings, overnight fasted).

\section{Materials and Methods}

\subsection{Participant}

The study participant for this case history study (33 years of age) was a professional endurance athlete, mountain climber, and adventurer. The participant voluntarily signed the informed consent form, and study procedures were submitted to and approved by the Institutional Review Board at Appalachian State University.

\subsection{8-Week Data Collection}

Study procedures were developed to induce a low participant burden and were reviewed with the study participant prior to providing voluntary consent. Basic demographic, lifestyle, exercise training, and nutrient intake data were obtained using standard questionnaires and logs.

Physical fitness performance test scores were measured during three sessions at the Human Performance Lab, and included body composition, mean and peak anaerobic power during the Wingate 30-s sprint cycling test, and strength through handgrip and leg/back dynamometer tests. These lab fitness test sessions took place at the beginning of the 28-week monitoring period, and then after 7 weeks and 25 weeks ( 2 weeks post-Antarctica trek). Height and body weight were measured using a 
seca stadiometer and scale (Hanover, MD, USA). Body composition was measured with the Bod Pod body composition analyzer (Life Measurement, Concord, CA, USA). Leg-back dynamometer strength was assessed during a maximal lift test with arms straight and knees slightly bent using a bar that was attached to a platform via a chain and dynamometer (Lafayette Instruments, Lafayette, IN, USA). The test was repeated three times, with the highest score recorded. Handgrip dynamometer strength (Lafayette Instruments, Lafayette, IN, USA) was assessed using the best score from three maximal 2 to 3 s grips. The Lode cycle ergometer (Lode B.V., Groningen, The Netherlands) was used for the $30 \mathrm{~s}$ Wingate anaerobic power cycling test. The cycle ergometer was adjusted to the body mass of the subject (7 W per kilogram), with peak and total wattage power output recorded and adjusted to body mass.

Dried blood spot (DBS) specimens were collected via fingerprick onto standard blood spot cards (Whatman ${ }^{\circledR}$ protein saver cards, Sigma-Aldrich, St. Louis, MO, USA). The participant was instructed in the fingerprick blood sample procedure, and samples were collected weekly in an overnight fasted state (26 July 2018 to 7 February 2019, Thursday mornings). The DBS samples were shipped to ProteiQ Biosciences (Berlin, Germany) for proteomics analysis.

Training distress was monitored weekly (Thursday mornings when acquiring the DBS samples) using the training distress scale (TDS). The TDS is a 19 item self-reported questionnaire that calculates training distress and performance readiness during the previous $48 \mathrm{~h}$ [22]. The participant responded to these items by indicating the extent to which the symptom was experienced using a 5-point bipolar scale anchored by the phrases not at all (0) and extreme amount (4).

Food and nutrient intake were monitored during the Antarctica trek (Weeks 16 to 23) using dietary recall. Food items were meticulously portioned out for each day prior to the trek. The recall consisted of a description of the food or beverage consumed with the brand name, quantity, and amount consumed, and the method of preparation. Nutrient analysis was conducted using the Food Processor software system (v. 11.7.1) (ESHA Research, Salem, OR, USA).

\subsection{Proteomics Procedures}

Punches, $4 \mathrm{~mm}$ diameter wide, were punched out of the DBS samples and proteins were resolubilized in $6 \mathrm{M}$ urea, $50 \mathrm{mM}$ ammonium bicarbonate (AmBiC) and $0.1 \mathrm{mM}$ dithiothreitol for $30 \mathrm{~min}$ at $37^{\circ} \mathrm{C}$ while shaking. Proteins were then alkylated by adding $0.1 \mathrm{mM}$ iodoacetamide for $30 \mathrm{~min}$ in the dark at room temperature. After protein quantitation, $25 \mu \mathrm{g}$ of proteins were taken for further processing. Proteins were diluted to a final volume of $50 \mu \mathrm{L}$ with $50 \mathrm{mM} \mathrm{AmBiC}$ containing 1:50 ratio trypsin (Promega, V5111, Madison, WI, USA). Proteins were digested for $3 \mathrm{~h}$ at $37^{\circ} \mathrm{C}$ while shaking. Digestion was quenched by adding $1 \%$ formic acid (FA). Subsequently, peptides were cleaned using C18 96-well plates (Waters Corporation, Milford, MA, USA). Peptides were eluted from the column with $50 \%$ acetonitrile (ACN)/0.1\% FA. Samples were then lyophilized prior to nano-electrospray ionization liquid chromatography tandem mass spectrometry (nanoLC-MS/MS).

Before injection on the nanoLC-MS/MS, peptides were resolubilized in $50 \mu \mathrm{L}$ of $0.1 \%$ FA, and $3 \%$ can and $1 \mu \mathrm{g}$ of protein was used for nanoLC-MS/MS measurement. Pooled samples were run to monitor CV values and assess the quality of label-free quantitation. All samples were measured with a combination of a nano Acquity ultraperformance liquid chromatography (UPLC) system (Waters Corporation, Milford, MA, USA) and a Thermo Scientific Orbitrap Fusion Tribrid Mass Spectrometer in data independent analysis (DIA) mode (Thermo Fisher Scientific, Waltham, MA, USA). Peptides were separated on an analytical column ethylene bridged hybrid (BEH) C18, 130A, $1.7 \mu \mathrm{m}, 75 \mu \mathrm{m} \times$ $150 \mathrm{~mm}$ (Waters Corporation, Milford, MA, USA). Flowrate was $300 \mathrm{~nL} / \mathrm{min}$ (buffer A, $\mathrm{HPLC} \mathrm{H}_{2} \mathrm{O}$, $0.1 \%$ formic acid; buffer $\mathrm{B}, \mathrm{ACN}, 0.1 \%$ formic acid; $60 \mathrm{~min}$ run method, $40 \mathrm{~min}$ gradient 0 to $3 \mathrm{~min} 2 \%$ buffer B, 3 to 40 min nonlinear stepwise gradient from $2 \%$ to $>40 \%$ buffer B, 40 to $45 \mathrm{~min} 95 \%$ buffer B, 45 to 60 min 2\% buffer B). Eighteen MS2 windows were used for DIA with different widths for equal distribution of MS1 precursor intensity and a cycle time that led to $\sim 10$ points per chromatographic peak. After each cycle, 1 MS1 acquisition was inserted. MS2 was done at 30,000 resolution and an MS 
filling time of $54 \mathrm{~ms}$. The automatic gain control (AGC) target was set on $2.0 \times 10^{5}$. The MS1 resolution was 60,000 with an MS filling time of $110 \mathrm{~ms}$ and an AGC target of $1.0 \times 10^{6}$. An in-house dried blood spot library was used that was created previously.

\subsection{Data Processing}

The DIA files were processed by infineQ software (www.infineq.com) that is based on the DIA-neural networks algorithm [23] using standard settings with a false discovery rate (FDR) cut-off set to $1 \%$ for precursors. Retention times of the library were adapted to instrument specific retention times. Data was normalized using the CyCloess normalization approach and finally peptides were quantified into proteins.

\subsection{Statistics}

The 28-week period was divided into the following time segments based on the TDS scores: Weeks 1 to 4 (recovery and training following the 50 state peaks challenge event), Weeks 5 to 8 (relaxed Greenland training and practice), Weeks 9 to 15 (physical training, with an emphasis on strength), Weeks 16 to 19 (first month of Antarctica trek), Weeks 20 to 23 (second month of Antarctica trek), and Weeks 24 to 28 (recovery period). Weeks 5 to 8 had the lowest TDS scores and this time segment was set as the comparison period for all other time segments, with a focus on contrasts with the last portion of the Antarctica trek (Weeks 20 to 23) when TDS scores were highest.

For the linear models, the time segments comparisons were made by calculating the $\log 2$ fold-change ratios with the limma R package (v. 3.6.2, Bioconductor, Buffalo, NY, USA) [24] using as reference Weeks 5 to 8 (the Greenland period). The $\log 2$ ratios were obtained by defining a linear model for each protein. This approach estimates the mean values per time segment, and for each comparison between means, a two-sample moderated t-test is used to infer a p-value. The reported $p$-values were corrected for false discovery rate (FDR) and tested against an alpha value $<0.1$.

For the supervised classification analysis, we used sPLS-DA (sparse partial least squares discriminant analysis) [25] and LASSO (least absolute shrinkage and selection operation) [26] classification algorithms to find biomarkers specific to each time segment in order to discriminate among the different time segments. LASSO is a powerful regularization technique and incorporates an L1- penalization term into the loss function forcing some coefficients to be zero. Differences between scores from LASSO output were compared using the Kruskal-Wallis nonparametric rank sum test.

\subsection{Protein-Protein Interaction Network Analysis}

Proteins expressed were mapped onto STRING v11 to build protein-protein interaction (PPI) networks. STRING v11 (search tool for the retrieval of interacting genes and proteins) is a database of known and predicted physical and functional protein associations based on genomic context, high-throughput experiments, co-expression, and previous knowledge (http://string-db.org/) [5].

\section{Results}

The successful Antarctica trek covered $1500 \mathrm{~km}$ over 54 days from 3 November to 26 December 2018. The total TDS score was lowest during the four weeks of training in Greenland and peaked during the last four weeks of the Antarctica trek (Figure 1). 


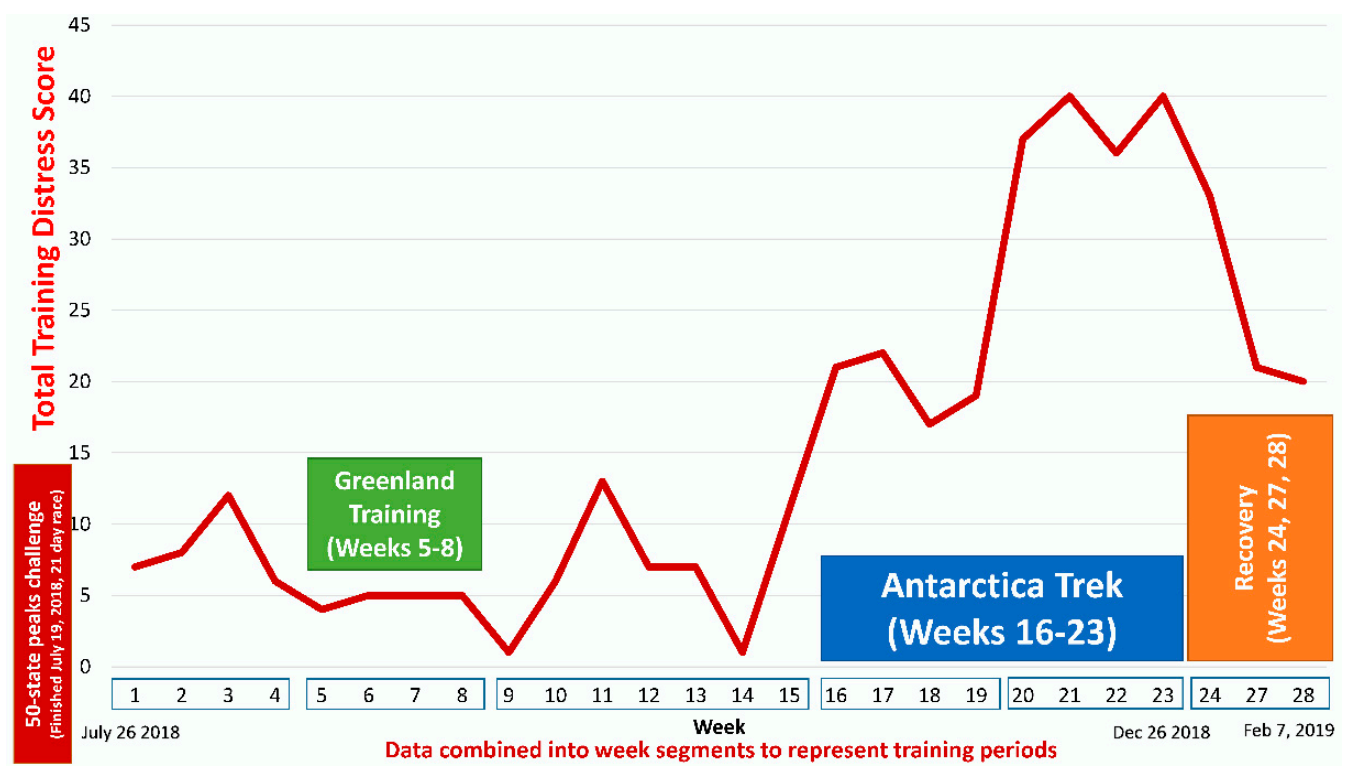

Figure 1. The total training distress score (TDS) during the 28-week monitoring period.

Physical fitness tests were conducted at Weeks 1, 9, and 25 (two weeks after completing the Antarctica trek) (Figure 2). The participant experienced a decrease of $11.4 \mathrm{~kg}$ in body mass, a $26 \%$ decrease in leg/back lifting strength, and an $18 \%$ and $30 \%$ decrease in anaerobic mean and peak power, respectively.
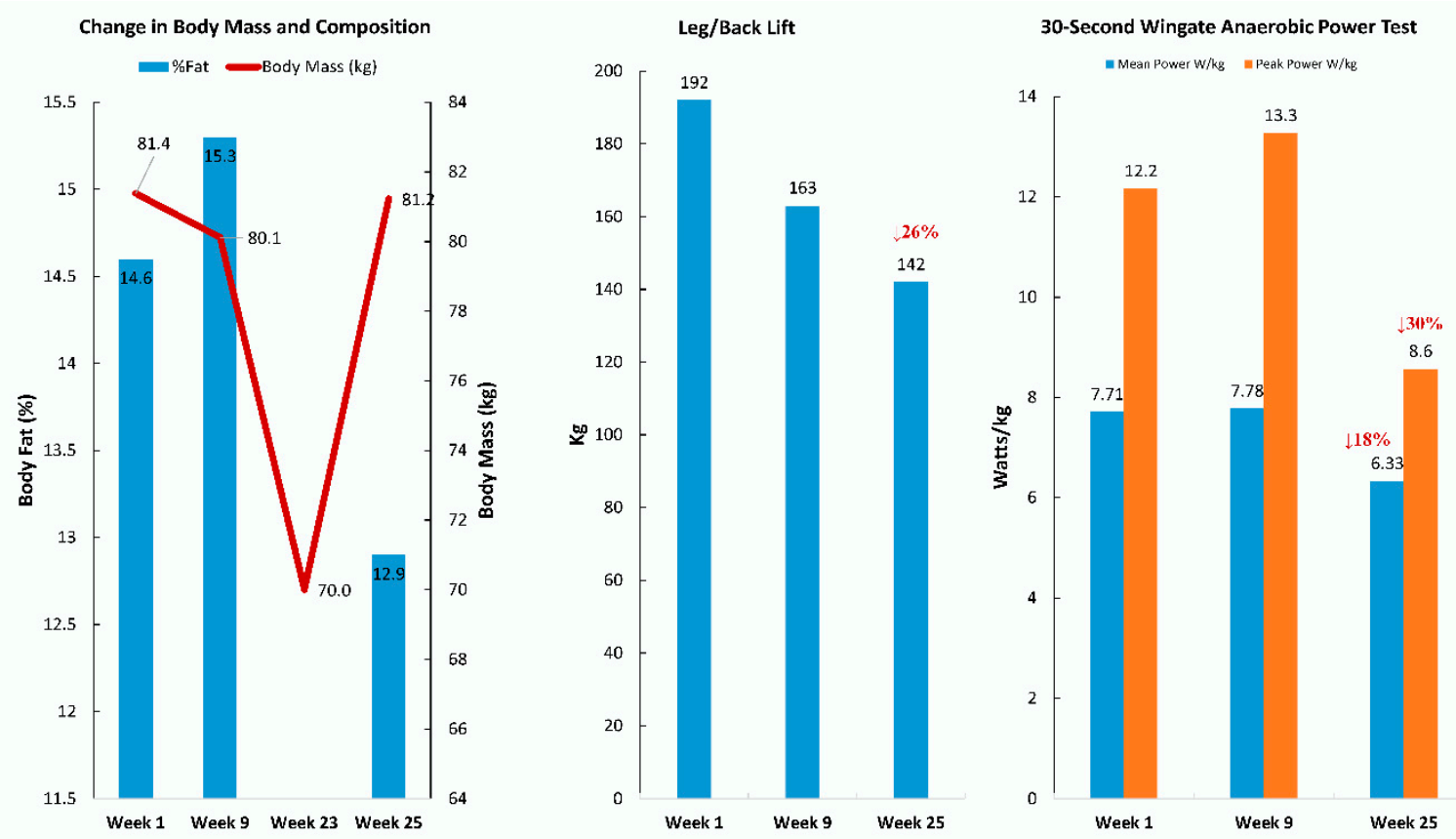

Figure 2. Physical fitness test scores at Weeks 1, 9, and 25.

During the Antarctica trek, the participant consumed an average of $7048 \mathrm{kcal} / \mathrm{day}$, with a macronutrient intake energy distribution of $45 \%$ carbohydrate, $44 \%$ fat, and $13 \%$ protein. This included approximately $4138 \mathrm{kcal} / \mathrm{day}$ from nutrient-dense sports bars (Standard Process Inc., Palmyra, WI, USA).

A total of 712 proteins were identified from the proteomics procedures (Supplemental Table S1). When the identified peptides were not clearly linked to a specific isoform (e.g., histones), 
the isoforms were classified as one protein. Supervised classification using sPLS-DA and LASSO successfully separated Weeks 20 to 23 (second month of the Antarctica trek) from all other week segments. The contrast analysis between Weeks 5 to 8 (Greenland training) and Weeks 20 to 23 showed that 31 proteins were upregulated (Table 1) and 35 (Table 2) were downregulated.

Table 1. Proteins upregulated $(n=31)$ during the last month (Weeks 20-23) of the Antarctica trek as compared with Weeks 5 to 8 (Greenland training) (adjusted $p$-value $<0.100$ ). Proteins are ordered by log-fold increase. Proteins in bold were involved with the immune response in protein-protein interaction (PPI) networks. ${ }^{\dagger}=$ extracellular or secreted; $\ddagger=$ intracellular.

\begin{tabular}{|c|c|c|c|c|c|}
\hline Gene & UniProt Identifier & Protein Description & $\begin{array}{l}\text { Log-Fold } \\
\text { Change }\end{array}$ & $p$-Value & $\begin{array}{c}\text { Adjusted } \\
p \text {-Value }\end{array}$ \\
\hline APOE & P02649 & apolipoprotein $\mathrm{E}^{\dagger}$ & 1.856 & 0.000 & 0.000 \\
\hline GPX3 & P22352 & glutathione peroxidase $3^{\dagger}$ & 1.590 & 0.000 & 0.000 \\
\hline APOC3 & P02656 & apolipoprotein $\mathrm{C}^{\dagger}$ & 1.574 & 0.000 & 0.001 \\
\hline APOD & P05090 & apolipoprotein $\mathrm{D}^{\dagger}$ & 1.559 & 0.000 & 0.000 \\
\hline HGFAC & Q04756 & HGF activator $^{\dagger}$ & 1.467 & 0.000 & 0.006 \\
\hline APOC2 & P02655 & apolipoprotein $\mathrm{C}^{\dagger}$ & 1.463 & 0.000 & 0.003 \\
\hline RBP4 & P02753 & retinol binding protein $4^{+}$ & 1.412 & 0.000 & 0.001 \\
\hline APOM & O95445 & apolipoprotein $\mathrm{M}^{\dagger}$ & 0.984 & 0.000 & 0.007 \\
\hline HDHD2 & Q9H0R4 & $\begin{array}{c}\text { haloacid dehalogenase like } \\
\text { hydrolase domain containing } 2^{\dagger}\end{array}$ & 0.976 & 0.001 & 0.038 \\
\hline SERPINA4 & P29622 & $\begin{array}{c}\text { serpin family A member } 4 ; \\
\text { kallistatin }^{\dagger}\end{array}$ & 0.971 & 0.002 & 0.038 \\
\hline APOC1 & P02654 & apolipoprotein $\mathrm{C}^{\dagger}$ & 0.970 & 0.000 & 0.003 \\
\hline SERPING1 & P05155 & $\begin{array}{l}\text { serpin family G member } 1 ; \\
\text { plasma protease } C 1 \text { inhibitor }\end{array}$ & 0.947 & 0.002 & 0.041 \\
\hline CLNS1A & P54105 & $\begin{array}{c}\text { chloride nucleotide-sensitive } \\
\text { channel } 1 \mathrm{~A}^{\ddagger}\end{array}$ & 0.898 & 0.007 & 0.076 \\
\hline $\begin{array}{c}\text { HIST1H3A-J; } \\
\text { H3F3A; H3F3B; } \\
\text { HIST3H3; } \\
\text { HIST2H3A,C,D }\end{array}$ & $\begin{array}{l}\text { P68431; } \\
\text { P84243; } \\
\text { Q16695; } \\
\text { Q71DI3 }\end{array}$ & $\begin{array}{c}\text { histone cluster } 1 \text { H3 family } \\
\text { member a-j; } \neq \\
\text { H3 histone family members } \\
\text { 3A,3B; } \ddagger \\
\text { histone cluster } 3 \mathrm{H} 3 ; \ddagger \\
\text { histone cluster } 2 \text { H3 family } \\
\text { member a,c, } \mathrm{d}^{\ddagger}\end{array}$ & 0.897 & 0.006 & 0.074 \\
\hline C8G & P07360 & complement C8 gamma chain $^{\dagger}$ & 0.864 & 0.008 & 0.086 \\
\hline C1R & P00736 & complement $\mathrm{C}_{1 \mathrm{r}^{\dagger}}$ & 0.810 & 0.001 & 0.028 \\
\hline APOA1 & P02647 & apolipoprotein $\mathbf{A 1}^{\dagger}$ & 0.797 & 0.000 & 0.001 \\
\hline CPN2 & P22792 & carboxypeptidase $\mathrm{N}$ subunit $2^{\dagger}$ & 0.793 & 0.002 & 0.038 \\
\hline CPN1 & P15169 & carboxypeptidase $\mathbf{N}$ subunit $\mathbf{1}^{\dagger}$ & 0.763 & 0.002 & 0.041 \\
\hline AGT & P01019 & angiotensinogen $^{\dagger}$ & 0.680 & 0.002 & 0.041 \\
\hline ITIH4 & Q14624 & $\begin{array}{l}\text { inter-alpha-trypsin inhibitor } \\
\text { heavy chain } 4^{+}\end{array}$ & 0.648 & 0.001 & 0.033 \\
\hline PLG & P00747 & plasminogen $^{\dagger}$ & 0.621 & 0.000 & 0.017 \\
\hline APOA2 & P02652 & apolipoprotein $\mathrm{A2}^{+}$ & 0.603 & 0.000 & 0.019 \\
\hline AFM & P43652 & $\operatorname{afamin}^{\dagger}$ & 0.602 & 0.004 & 0.064 \\
\hline PON1 & P27169 & paraoxonase $1^{\dagger}$ & 0.590 & 0.002 & 0.042 \\
\hline SERPINA6 & P08185 & $\begin{array}{l}\text { serpin family A member } 6 \\
\text { (cortisol binding globulin) }\end{array}$ & 0.585 & 0.001 & 0.034 \\
\hline A1BG & P04217 & alpha-1-B glycoprotein $^{\dagger}$ & 0.577 & 0.001 & 0.038 \\
\hline $\mathrm{C5}$ & P01031 & complement $\mathrm{C}^{\dagger}$ & 0.547 & 0.003 & 0.054 \\
\hline TTR & P02766 & transthyretin $^{\dagger}$ & 0.498 & 0.004 & 0.064 \\
\hline AZGP1 & P25311 & $\begin{array}{l}\text { alpha-2-glycoprotein 1, } \\
\text { zinc-binding }{ }^{+}\end{array}$ & 0.468 & 0.006 & 0.075 \\
\hline CLU & P10909 & clusterin ${ }^{\dagger \ddagger}$ & 0.439 & 0.002 & 0.038 \\
\hline
\end{tabular}


Table 2. Proteins downregulated $(n=35)$ during the last month (Weeks 20 to 23) of the Antarctica trek compared to Weeks 5 to 8 (Greenland training) (adjusted $p$-value $<0.100$ ). Proteins are ordered by $\log$ -old decrease. Proteins in bold were involved with the immune response in protein-protein interaction (PPI) networks. $\dagger=$ extracellular or secreted; $\ddagger=$ intracellular.

\begin{tabular}{|c|c|c|c|c|c|}
\hline Gene & $\begin{array}{l}\text { UniProt } \\
\text { Identifier }\end{array}$ & Protein Description & $\begin{array}{l}\text { Log-Fold } \\
\text { Change }\end{array}$ & $p$-Value & $\begin{array}{c}\text { Adjusted } \\
p \text {-Value }\end{array}$ \\
\hline ACLY & P53396 & ATP citrate lyase $e^{\ddagger}$ & -0.274 & 0.008 & 0.088 \\
\hline YWHAE & P62258 & $\begin{array}{c}\text { tyrosine 3-monooxygenase/tryptophan } \\
\text { 5-monooxygenase activation protein } \\
\text { epsilon } \ddagger\end{array}$ & -0.287 & 0.004 & 0.065 \\
\hline ARF1; ARF3 & $\begin{array}{l}\text { P61204; } \\
\text { P84077 }\end{array}$ & ADP ribosylation factors $1,3^{\ddagger}$ & -0.300 & 0.005 & 0.065 \\
\hline PSMC6 & P62333 & proteasome $26 \mathrm{~S}$ subunit, ATPase $6^{\ddagger}$ & -0.319 & 0.006 & 0.074 \\
\hline PSMD9 & O00233 & proteasome $26 \mathrm{~S}$ subunit, non-ATPase $9 \ddagger$ & -0.356 & 0.008 & 0.089 \\
\hline PSMC5 & P62195 & proteasome $26 \mathrm{~S}$ subunit, ATPase $5^{\ddagger}$ & -0.358 & 0.009 & 0.095 \\
\hline PA2G4 & Q9UQ80 & proliferation-associated 2G4 ${ }^{\ddagger}$ & -0.383 & 0.002 & 0.041 \\
\hline $\begin{array}{l}\text { HSPA1A; } \\
\text { HSPA1B }\end{array}$ & P08107 & $\begin{array}{l}\text { heat shock protein family A (Hsp70) } \\
\text { members 1A, } 1 B^{\ddagger}\end{array}$ & -0.386 & 0.003 & 0.045 \\
\hline $\mathrm{XPO} 7$ & Q9UIA9 & exportin $7^{\ddagger}$ & -0.392 & 0.006 & 0.076 \\
\hline IL10 & P22301 & interleukin $10^{\dagger}$ & -0.408 & 0.006 & 0.074 \\
\hline CAPZA1 & P52907 & $\begin{array}{l}\text { capping actin protein of muscle Z-line } \\
\text { subunit alpha } 1^{\dagger}\end{array}$ & -0.432 & 0.000 & 0.017 \\
\hline IGLV1-47 & P01700 & immunoglobulin lambda variable $1-47^{\dagger}$ & -0.447 & 0.005 & 0.065 \\
\hline IGKC & P01834 & immunoglobulin kappa constant $^{+}$ & -0.472 & 0.002 & 0.044 \\
\hline LGALS3 & P17931 & galectin $3^{+\ddagger}$ & -0.479 & 0.007 & 0.078 \\
\hline LCP1 & P13796 & lymphocyte cytosolic protein $1^{\ddagger}$ & -0.480 & 0.002 & 0.043 \\
\hline CALM1,2,3 & P62158 & calmodulin $1,2,3^{\ddagger}$ & -0.484 & 0.002 & 0.038 \\
\hline PCBP1 & Q15365 & poly $(\mathrm{rC})$ binding protein $1^{\ddagger}$ & -0.544 & 0.006 & 0.074 \\
\hline AHSP & Q9NZD4 & alpha hemoglobin stabilizing protein ${ }^{\dagger \ddagger}$ & -0.607 & 0.001 & 0.033 \\
\hline RGS10 & O43665-3 & regulator of $G$ protein signaling $10^{\ddagger}$ & -0.744 & 0.003 & 0.051 \\
\hline CPPED1 & Q9BRF8 & $\begin{array}{l}\text { calcineurin like phosphoesterase domain } \\
\text { containing } 1^{+\ddagger}\end{array}$ & -0.773 & 0.003 & 0.052 \\
\hline DHRS11 & Q6UWP2 & dehydrogenase/reductase $11^{\dagger \ddagger}$ & -0.794 & 0.005 & 0.071 \\
\hline ADK & P55263 & adenosine kinase $\mathrm{f}^{\ddagger}$ & -0.837 & 0.002 & 0.043 \\
\hline STMN2 & Q93045 & stathmin $2^{\ddagger}$ & -0.860 & 0.001 & 0.024 \\
\hline FSCB & Q5H9T9 & fibrous sheath CABYR binding protein ${ }^{\dagger \ddagger}$ & -0.891 & 0.004 & 0.063 \\
\hline EEF2 & P13639 & $\begin{array}{l}\text { eukaryotic translation elongation factor } \\
\qquad 2^{\ddagger}\end{array}$ & -0.897 & 0.000 & 0.006 \\
\hline $\begin{array}{l}\text { YWHAB; } \\
\text { YWHAG; } \\
\text { YWHAQ }\end{array}$ & $\begin{array}{l}\text { P31946; } \\
\text { P61981; } \\
\text { P27348 }\end{array}$ & $\begin{array}{l}\text { tyrosine 3-monooxygenase/tryptophan } \\
\text { 5-monooxygenase activation protein beta; } \\
\text { gamma; theta }{ }^{\ddagger}\end{array}$ & -0.897 & 0.006 & 0.074 \\
\hline ITGB3 & P05106 & integrin subunit beta $3^{\ddagger}$ & -1.081 & 0.004 & 0.059 \\
\hline RAB6A & P20340-2 & RAB6A, member RAS oncogene family & -1.090 & 0.003 & 0.053 \\
\hline EEF1A1 & $\begin{array}{l}\text { P68104; } \\
\text { Q5VTE0 }\end{array}$ & $\begin{array}{c}\text { eukaryotic translation elongation factor } 1 \\
\text { alpha } 1^{\ddagger}\end{array}$ & -1.190 & 0.001 & 0.033 \\
\hline HBM & Q6B0K9 & hemoglobin subunit $\mathrm{mu}^{\ddagger}$ & -1.196 & 0.000 & 0.001 \\
\hline $\begin{array}{l}\text { HIST1H2BB-K, } \\
\text { M-O }\end{array}$ & $\begin{array}{c}\text { P33778;P62807; } \\
\text { P58876;Q93079; } \\
\text { P06899;O60814; } \\
\text { Q99879;Q99877; } \\
\text { P23527;Q16778; } \\
\text { Q5QNW6 }\end{array}$ & $\begin{array}{l}\text { histone cluster } 1 \mathrm{H} 2 \mathrm{~B} \text { family members } \\
\text { b-k, m-0; }{ }^{\ddagger} \\
\text { cluster } 2 \text { H2B family members e, } f^{\ddagger}\end{array}$ & -1.301 & 0.000 & 0.020 \\
\hline CLLU1OS & Q5K130 & $\begin{array}{c}\text { chronic lymphocytic leukemia upregulated } \\
1 \text { opposite strand } \mathrm{d}^{+\ddagger}\end{array}$ & -1.303 & 0.002 & 0.040 \\
\hline DYNC1H1 & Q14204 & dynein cytoplasmic 1 heavy chain $1^{\ddagger}$ & -1.325 & 0.000 & 0.018 \\
\hline S100A9 & P06702 & S100 calcium binding protein $\mathrm{A}^{+}$ & -1.357 & 0.006 & 0.075 \\
\hline S100A8 & P05109 & S100 calcium binding protein $\mathrm{A}^{+}$ & -1.680 & 0.001 & 0.032 \\
\hline
\end{tabular}


Protein-protein interaction (PPI) networks were constructed separately for the proteins listed in Tables 1 and 2 using the Search Tool for Retrieval of Interacting Genes/Proteins (STRING). Of the 31 proteins listed in Table 1 that increased during the last four weeks of the Antarctica trek, $n=20$ were included in immune system-related, biological process GO terms, with an average local cluster coefficient of 0.697 (PPI enrichment $p$-value < 0.0001) (Figure 3). The mean log-fold increase for all 20 proteins was 0.85 during the last four weeks of the Antarctica trek and 0.92 during the five weeks of recovery as compared with the reference week segment (Weeks 5 to 8, Greenland training). Biological process GO terms from STRING supported an increase in regulation of the immune system process, complement activation, proteolysis, the inflammatory response, platelet degranulation, and leukocyte mediated immunity. Most of the upregulated proteins were extracellular or secreted.

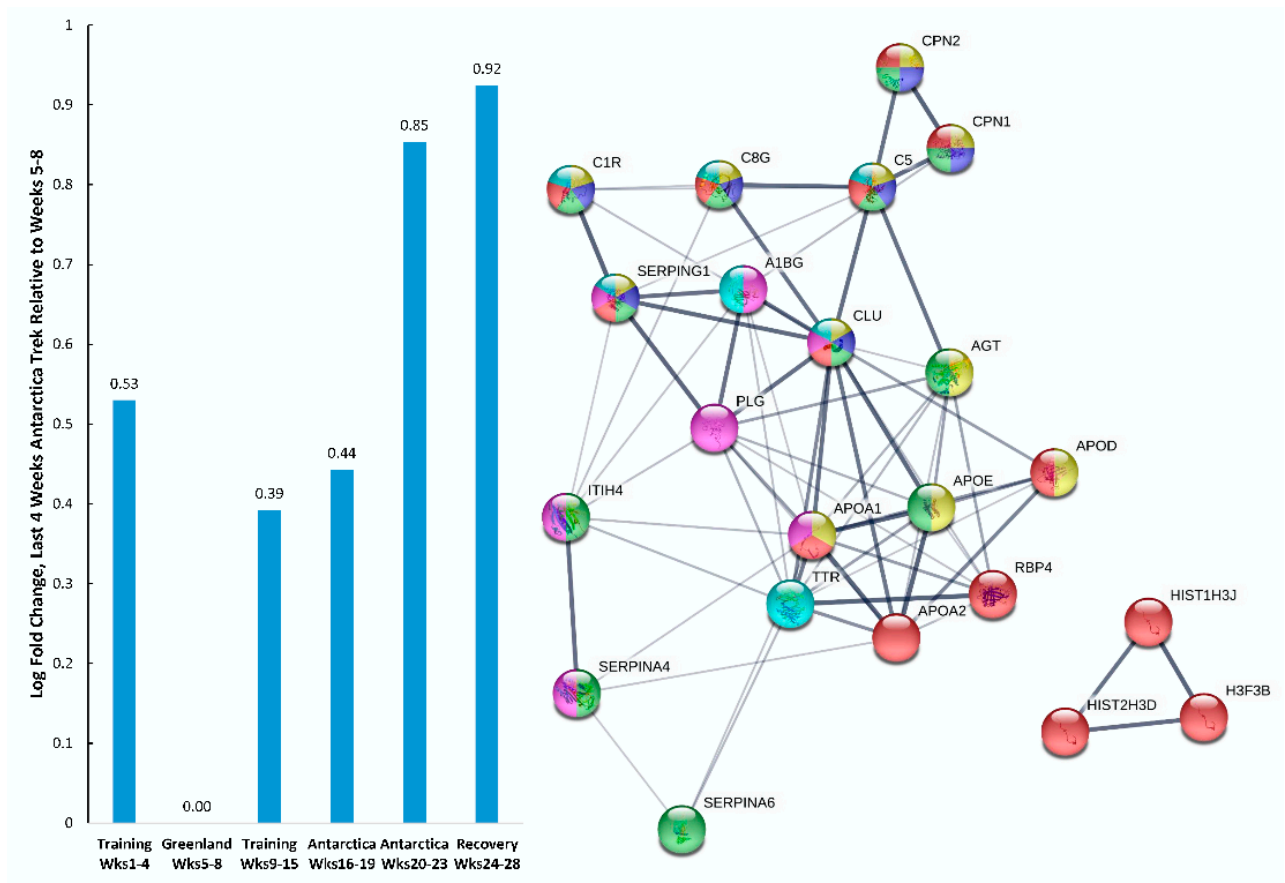

Figure 3. Protein-protein interaction (PPI) network for blood immune-related proteins $(n=22)$ that increased during the last four weeks of the Antarctica trek as compared with the reference week segment (Weeks 5 to 8). Gene ontology (GO) terms for biological process were coded as follows: Red, regulation of immune system process; dark blue, regulation of complement activation; green, regulation of proteolysis; yellow, regulation of inflammatory response; pink, platelet degranulation; and light blue, leukocyte mediated immunity. Acronyms represent upregulated genes (see Table 1 for descriptions).

During the Antarctica trek, the participant consumed approximately 8000 kilocalories per day, and this was supplied from high-fat energy bars that were formulated for this event. Fourteen proteins from Table 1 were included in nutrition-related, biological process GO terms, with an average local cluster coefficient of 0.883 (PPI enrichment p-value < 0.0001) (Figure 4). The mean log-fold increase for all 14 proteins was 1.00 during the last four weeks of the Antarctica trek and 0.99 during the five weeks of recovery as compared with the reference week segment (Weeks 5 to 8, Greenland training). Biological process GO terms from STRING supported an increase in plasma lipoprotein particle remodeling, regulation of lipid transport, retinoid metabolic process, and vitamin transport. Most of the downregulated proteins were intracellular. 


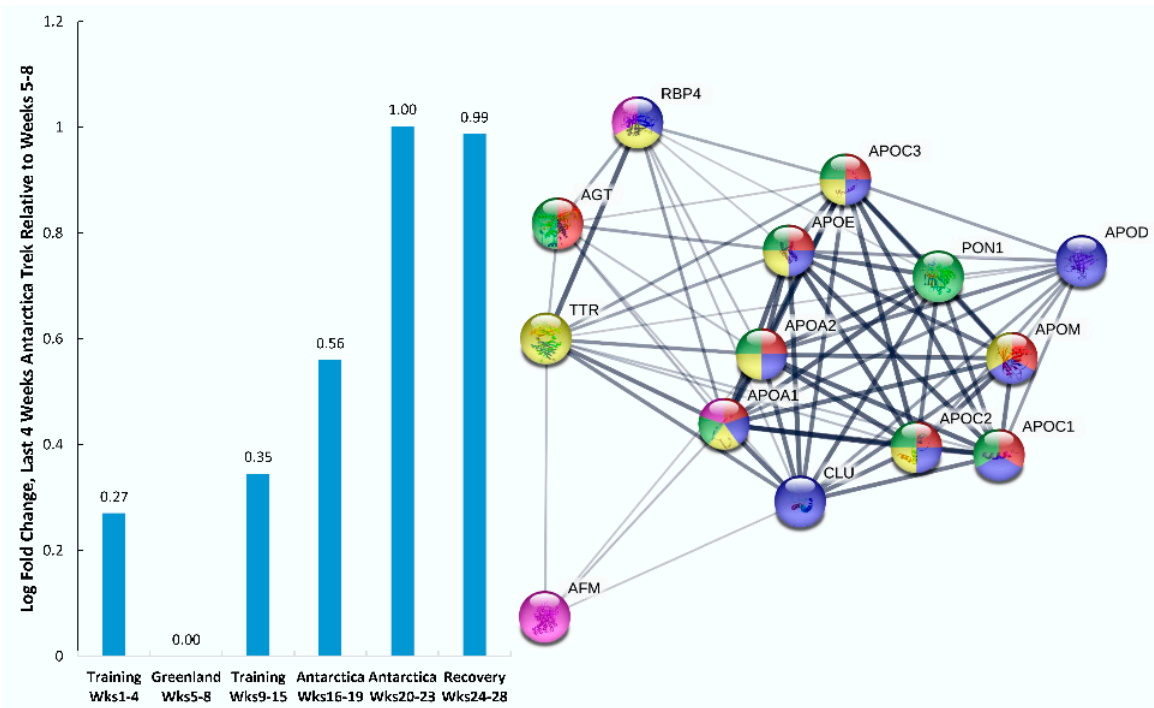

Figure 4. PPI network for nutrition-related proteins $(n=14)$ that increased during the last four weeks of the Antarctica trek as compared with the reference week segment (Weeks 5 to 8). GO terms for biological process were coded as follows: Red, plasma lipoprotein particle remodeling; dark blue, lipid transport; green, regulation of lipid transport; yellow, retinoid metabolic process; and pink, vitamin transport. Acronyms represent upregulated genes (see Table 1 for descriptions).

Of the 35 proteins listed in Table 2 that decreased during the last four weeks of the Antarctica trek, $n=17$ were included in immune system-related, biological process GO terms, with an average local cluster coefficient of 0.741 (PPI enrichment $p$-value $<0.0001$ ) (Figure 5). The mean log-fold decrease for all 17 proteins was -0.83 during the last four weeks of the Antarctica trek and -0.33 during the five weeks of recovery as compared with the reference week segment (Weeks 5 to 8, Greenland training). Biological process GO terms from STRING supported a decrease in the immune system process, neutrophil degranulation, vesicle mediated transport, and antimicrobial humoral response.

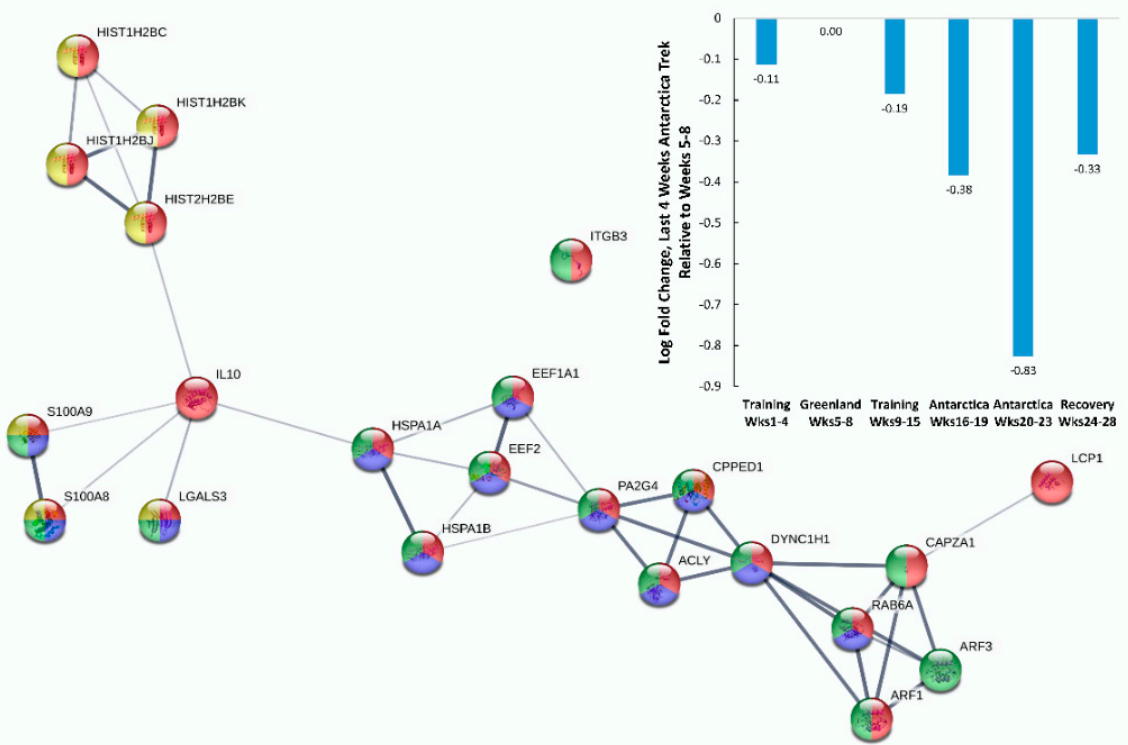

Figure 5. PPI network for immune-related proteins $(n=17)$ that decreased during the last four weeks of the Antarctica trek as compared with the reference week segment (Weeks 5 to 8 ). GO terms for biological process were coded as follows: Red, immune system process; dark blue, neutrophil degranulation; green, vesicle mediated transport; and yellow, antimicrobial humoral response. Acronyms represent downregulated genes (see Table 2 for descriptions). 
During the 5-week recovery period, three DBS samples were obtained (Weeks 1, 4, and 5). A total of 65 proteins (42 immune-related) were significantly upregulated as compared with Weeks 5 to 8 , and 65 (30 immune-related) were significantly downregulated (Table S1). Of the upregulated immune-related proteins, most were linked to inflammation with some of the greatest fold increases seen for attractin, serum amyloid A4, serpin family F member 1, kallikrein B1, fibronectin 1, alpha 2-HS glycoprotein, inter-alpha-trypsin inhibitor heavy chain4, vitronectin, hemopexin, kininogen 1, protein $\mathrm{S}$, and several complement proteins (Table S1). Of the downregulated immune-related proteins, seven were related to the IL-12-mediated signaling pathway, 10 to neutrophil degranulation, and 13 to actin filament and cytoskeleton organization (Table S1).

\section{Discussion}

An elite adventure athlete was successfully monitored for 28 weeks, with weekly DBS samples analyzed for shifts in 712 blood proteins. The athlete cycled through various phases of training that culminated in the successful solo trek across the Antarctica. Protein data from the DBS samples were grouped according to training periods based on TDS scores, with the greatest contrast seen between Weeks 5 to 8 (relaxed Greenland training) and the last month of the Antarctica trek (Weeks 20 to 23) when shifts in 67 blood proteins were observed. Of these proteins, 31 were upregulated, and 35 were downregulated, with over half (56\%) related to immune system function and 14 linked to nutrition-related processes.

The log-fold change in upregulated immune-related proteins $(n=20)$ was considerable and was maintained throughout five weeks of recovery from the Antarctica trek. The PPI analysis and related GO terms supported an increase in regulation of the immune system process, especially leukocyte mediated immunity, complement activation, the inflammatory response, and platelet degranulation. At the same time, 14 proteins linked to nutritional effects were upregulated. PPI and GO terms supported an increase in plasma lipoprotein particle remodeling, regulation of lipid transport, retinoid metabolic process, and vitamin transport. Eight of these proteins performed dual roles with key involvement in the immune response, and these included apolipoproteins (apo) A1, A2, D, and E, retinol binding protein, clusterin, transthyretin, and angiotensinogen.

ApoE interacts with the low-density lipoprotein receptor (LDLR) to mediate the transport of cholesterol- and triglyceride-rich lipoprotein particles into cells via receptor-mediated endocytosis [27]. In contrast, apoAI is the major protein constituent of high-density lipoprotein (HDL) that mediates reverse cholesterol transport out of cells. ApoE and apoA1 are synthesized primarily in the liver but can also be expressed by lung cells where they help attenuate inflammation, oxidative stress, and tissue remodeling responses, while augmenting adaptive immunity and host defense [27]. ApoE receptor 2, one of the LDLR family members expressed in macrophages, can bind to its ligand apoE, exhibiting an anti-inflammatory role in atherosclerosis [27]. Additional evidence suggests that apoE and C-reactive protein (CRP) are negatively related [28]. Our data support that apoA1, apoA2, apoD, and apoE are involved in lipid transport, but also play a role in the immune and inflammation response to stressful levels of exercise. This appears to be a novel finding that will require additional research.

Recent findings support that clusterin is also involved in both lipid transport and inflammation [29]. Clusterin, also known as apolipoprotein $\mathrm{J}$, is induced in response to a wide variety of tissue injuries. Clusterin has chaperone activity, is a functional homolog to small heat shock proteins, and binds hydrophobic domains of numerous non-native proteins, targeting them for receptor-mediated internalization and lysosomal degradation. Clusterin also interacts with a broad spectrum of molecules including lipids, components of the complement system, amyloid-forming proteins, and immunoglobulins [30]. Our data support that clusterin played a dual role in regulating the immune response during the stressful Antarctica trek and in interacting with lipoprotein particle remodeling. This finding has not been previously reported.

Upregulated immune-related proteins during the Antarctica trek and five weeks of recovery included numerous proteins from the complement system. The complement system is composed 
of over 30 proteins and becomes activated in response to overreaching during athletic training, tissue injury, invading pathogens, or exposure to other foreign surfaces $[4,7,31,32]$. Complement $5 \mathrm{a}$ (C5a), for example, is secreted by liver cells and macrophages, and is essential to the innate immune response, and promotes inflammatory reactions. C5a is an important proinflammatory mediator that is cleaved enzymatically from C5 on activation of the complement cascade. C5a is quickly metabolized by carboxypeptidases (as supported by our data in Figure 3), forming the less-potent C5a des arginine (desArg). C5a and C5a desArg interact with their receptors resulting in widespread effects essential to the immune response including clearance of pathogens, host defense, increased vascular permeability, chemotaxis of inflammatory cells, respiratory burst activity, cytokine and chemokine release, phagocytosis, adaptive immunity, and coagulation [32]. Our data support a large increase in C5a and complement activation in response to extended mental and physical stress and is consistent with prior proteomics-based studies from our research group [4,7].

Lipocalin proteins are involved in inflammation caused by immune system activation. Lipocalins include several proteins that were upregulated during the Antarctica trek including apoD, retinol-binding protein, and C8 gamma (C8G) $[33,34]$. ApoD is an acid glycoprotein and is elevated in disease states such as prostate cancer and Alzheimer's disease. $\mathrm{C} 8 \mathrm{G}$ is a part of the complement membrane attack complex, and we have previously shown that this complement is elevated during overreaching [4,7]. After secretion, retinol binding protein complexes with another plasma protein, transthyretin, which is a triiodothyronine binding protein in humans. Retinal binding protein is linked to other inflammatory markers and can induce the secretion of cytokines and adhesion molecules in macrophages and endothelial cells [34].

Transcortin, also known as corticosteroid-binding globulin (CBG) or serpin A6, is a protein produced in the liver in animals. In humans it is encoded by the SERPINA6 gene and an alpha globulin $[35,36]$. CBG was increased during the Antarctica trek, and has evolved as an important biomarker for exercise overreaching and overtraining [4,7]. The importance of CBG is highlighted by its ability to bind $80 \%$ to $90 \%$ of cortisol in plasma, leaving only about $4 \%$ to $5 \%$ circulating in the free fraction and the remainder bound loosely to albumin. CBG plays a role in the control of the inflammatory response, gluconeogenesis, and stress. While CBG does not act as a protease inhibitor, it is a substrate for neutrophil elastase [36].

Kallistatin is a unique serine protease inhibitor (serpin family A member 4) and was one of several serpins elevated during the Antarctica trek and five weeks of recovery. Kallistatin has many roles including suppression of cytokine signaling expression in macrophages $[37,38]$. Kallistatin antagonizes tumor necrosis factor (TNF)- $\alpha$ induced inflammation, oxidative stress, and apoptosis while enhancing bacterial clearance and exerting anti-inflammatory effects. The elevation of kallistatin during the Antarctica trek and recovery appears to represent one attempt by the immune system to restore homeostasis [38].

Another elevated protein was plasminogen, an acute phase protein which is the zymogen form of the serine protease plasmin [39]. Plasminogen plays a crucial role in fibrinolysis, as well as wound healing, immunity, tissue remodeling, and inflammation. Cellular uptake of fibrin degradation products leads to apoptosis, which represents one of the pathways for crosstalk between fibrinolysis and tissue remodeling. Plasminogen was one of many acute phase proteins that were significantly elevated either during the last month of the Antarctica trek or during recovery, and these included complements (C3, C4, factor B, CI inhibitor, or serpin family G member 1), protein S, vitronectin, inter- $\alpha$-trypsin inhibitor, hemopexin, serum amyloid A, fibronectin, angiotensinogen, transthyretin, and $\alpha-2$ HS glycoprotein. We and others have shown that acute phase proteins are important biomarkers for intense exertion and overreaching, and influence one or more stages of inflammation [4,7,14-18].

The upregulated of 20 immune-related proteins was countered by a downregulation of 16 proteins linked to a decrease in the immune system process, especially neutrophil degranulation, vesicle mediated transport, and antimicrobial humoral response. 
Neutrophils are the most abundant leukocytes in the circulation, and recruitment and activation of these cells are crucial for defense against invading pathogens $[40,41]$. Neutrophils respond quickly and deploy cytosolic granules containing enzymatic and chemical effectors. Azurophilic granules, specific granules, gelatinase granules, and secretory vesicles in neutrophils each have specific types of proteins and effectors that are released depending on the signaling pathway, context, and function outcome [41]. Azurophilic granules, for example, contain oxidant-producing enzymes such as myeloperoxidase, proteases such as elastase and cathepsin $\mathrm{G}$, and membrane-permeabilizing proteins such as lysozyme and defensins. Inappropriate recruitment and activation of neutrophils can lead to tissue damage during an exaggerated inflammatory response. Neutrophil degranulation is tightly regulated through a multistep process involving calcium-dependent and kinase-dependent signaling pathways, actin and microtubule reorganization pathways mediated by calcium and nucleotide guanosine triphosphase hydrolase enzymes, and fusion process cell-surface receptors [41]. Thus, precise control of neutrophil movement and degranulation is of particular importance and can explain why neutrophil degranulation was suppressed during the most stressful phase of the Antarctica trek. This viewpoint is supported by the strong decrease in blood S100-A8/A9 (calprotectin) during the last month of the Antarctica trek. Calprotectin, the most abundant protein in the neutrophil, is released during trauma, stress, and infection, promotes phagocyte migration and inflammation, and functions as an alarmin and endogenous danger-associated molecular pattern (DAMP) [42,43]. Excessive expression of calprotectin magnifies the inflammatory process and related damage, induces the secretion of multiple cytokines in inflammatory cells, and if not properly regulated, can induce a vicious cycle in certain disorders [43]. Together, these data suggest that neutrophil function and degranulation were strongly moderated when inflammation was high due to stressful exercise levels.

Galectin-3 promotes fibroblast proliferation and transformation and stimulates the phagocytosis of apoptotic cells and cellular debris by macrophages. Galectin-3 is highly expressed and secreted by macrophages [44,45]. Interleukin (IL)-10 increases the expression of intracellular galectin-3 through activation of signal transducer and activator of transcription 3 (STAT3) [44]. The low levels of galectin-3 and IL-10 during the physiologically stressful Antarctica trek is another indicator of diminished immune function. During short-term overreaching, galectin-3 is elevated [4,7], but the data from the current study indicates that downregulation occurs during extended training distress.

Several proteins that were downregulated during the Antarctica trek were related to actin cytoskeleton organization. Calprotectin, which was strongly decreased during the trek, plays a significant role in mediating the rapid rearrangement of the cytoskeleton, a prerequisite for successful cell migration, phagocytosis, and exocytosis [43]. The actin cytoskeleton is a complex network controlled by an array of actin-binding proteins including plastins that non-covalently crosslink actin filaments into tight bundles [46]. Elongation factors, which were also downregulated during the trek, are essential for protein synthesis and have multiple immune-related roles including promotion of actin and cytoskeleton organization, detection and targeting of misfolded proteins for proteolytic degradation, and induction of cytotoxic T cells and heat shock protein 70 [47]. Cytoplasmic dynein 1 acts as a motor for the intracellular retrograde motility of vesicles and organelles along microtubules, is involved with neutrophil degranulation, and can help coordinate actin and microtubule organization at the immune synapse [48]. F-actin-capping protein subunit alpha-1 regulates growth of the actin filament by capping the barbed end (plus-end) of growing actin filaments, preventing any further assembly from occurring. Moesin is a major component of the cytoskeleton in neutrophils and helps link filamentous actin to the plasma membrane [49]. Moesin contributes to the slow rolling and subsequent recruitment of neutrophils during inflammation [50]. Our data support a decrease in moesin, especially during the 5-week recovery time period. Stomatin, another downregulated protein during the five weeks of recovery, can have a structural role for the anchorage to the actin cytoskeleton in neutrophils [51]. These data collectively support that actin cytoskeleton remodeling was decreased during the Antarctica trek and recovery, adding to the overall finding that neutrophil function and degranulation were mitigated, perhaps to reduce undue tissue damage. 


\section{Conclusions}

Recent improvements in MS-based proteomics procedures allow highly specific measurements of multiple protein patterns from small amounts of blood [52]. This greatly improves upon the earlier pursuit of NFOR and OTS biomarkers that used a few targeted outcomes, and offers a fresh, unbiased, hypothesis-free approach. In this study, proteomics monitoring of an elite adventure athlete during a 28-week period of normal training and overtraining revealed up- and downregulation of 14 nutrition-related and 37 immune-related proteins. These protein shifts were most evident when energy expenditure was highest, body mass was reduced, and training distress was most severe during the last month of the trek across the Antarctica. The athlete also experienced a decrease in performance measures that is consistent with NFOR and OTS [1]. These case history data could or coud not be applicable to other athletes but will provide direction for future studies. The DBS proteomics procedure is not able to distinguish proteins derived from intracellular and extracellular sources. Nonetheless, using available information, we determined that most of the upregulated proteins were from extracellular sources or were secreted, and that most of the downregulated proteins were from intracellular sources.

There is scant evidence available regarding most of these immune-related proteins within the field of exercise and nutrition immunology, in part due to an underutilization of proteomics methods. The PPI analysis and related GO terms supported an increase in regulation of the immune system process highlighted by inflammation, complement activation, and platelet degranulation that occurred at the same time that neutrophil degranulation, vesicle mediated transport, and antimicrobial humoral responses were suppressed. The heightened immune response continued unabated during the 5-week recovery process. Many of the upregulated and downregulated immune-related proteins identified in this case history study can be regarded as candidate biomarkers for NFOR and OTS in future studies of athletic groups. On the basis of our prior studies [4,7] and the data from this study, key NFOR and OTS biomarkers would include the following upregulated immune-related proteins $(n=28$ during both the Antarctica trek and recovery): kallistatin (serpin family A member 4), plasma protease C1 inhibitor (serpin family G member 1), complement proteins (C1r, C1s, C2, C3, C4-A, C5, C8 gamma, factor I, factor $\mathrm{B}$, factor $\mathrm{H}$ ), carboxypeptidase $\mathrm{N}$ subunits 1 and 2, angiotensinogen, inter-alpha-trypsin inhibitor heavy chain 4, plasminogen, corticosteroid-binding globulin (serpin family A member 6), alpha-1-B glycoprotein, clusterin, attractin, serpin family F member 1 (pigment epithelium-derived factor), plasma kallikrein, fibronectin, alpha 2-HS glycoprotein, vitronectin, kininogen-1, and serum amyloid A-4. Nine downregulated proteins are also included on the NFOR and OTS list which include: proliferation-associated 2G4, IL-10, galactin-3, calcineurin like phosphoesterase domain containing 1, dynein cytoplasmic 1 heavy chain 1, S100A8 and S100A9, moesin, and stomatin. Taken together, these proteomics data support a dichotomous immune response to sustained physiological stress in the harsh environment of the Antarctica highlighted by inflammation and complement activation with downregulated neutrophil degranulation and humoral immunity.

Supplementary Materials: The following are available online at http://www.mdpi.com/2227-7382/8/1/4/s1. TableS1 provides a list of the identified proteins that were included in the statistical analysis, with mean log-fold change and statistical data for each time segment compared to weeks 5-8 (XLSX).

Author Contributions: Conceptualization, D.C.N., A.J.G., A.P., A.J.S., K.P., and S.V; methodology, D.C.N., A.J.G., A.P., A.J.S., K.P., S.V., and C.H.-A.; formal Analysis, D.C.N., A.J.G., A.P., and C.H.-A.; investigation, D.C.N., A.J.G., A.P., A.J.S., K.P., and S.V.; resources, D.C.N., A.J.G., A.P., A.J.S., K.P., K.J., B.F.E.-K., C.H.-A., and S.V.; data Curation, A.J.G., A.P., and C.H.-A.; writing—original draft preparation, D.C.N.; writing—review and editing, D.C.N., A.J.G., A.P., A.J.S., K.P., S.V., B.F.E.-K., and C.H.-A.; supervision, D.C.N., A.J.G., S.V., and A.P.; project administration, D.C.N.; funding acquisition, D.C.N., A.J.G., and A.P. All authors have read and agreed to the published version of the manuscript.

Funding: This research was funded by Standard Process.

Conflicts of Interest: A.J.G. and A.P. are founders and owners of ProteiQ (Berlin, Germany). K.P., K.J., B.F.E.-K., and S.V. are scientists working for Standard Process (Standard Process Nutrition Innovation, Kannapolis, NC USA 28081). The rest authors declare no conflict of interest. 


\section{Abbreviations}

The following abbreviations were used in this manuscript:

\begin{tabular}{|c|c|}
\hline $\mathrm{ACN}$ & Acetonitrile \\
\hline AGC & Automatic gain control \\
\hline $\mathrm{AmBiC}$ & Ammonium bicarbonate \\
\hline $\mathrm{APO}$ & Apolipoprotein \\
\hline $\mathrm{C} 5 \mathrm{a}$ & Complement 5a \\
\hline C8G & Complement C8 gamma \\
\hline CBG & Cortisol-binding globulin \\
\hline CRP & C-reactive protein \\
\hline DAMP & Danger-associated molecular pattern \\
\hline desARG & Des arginine \\
\hline DIA & Data independent acquisition \\
\hline DIA-NN & Data independent acquisition-neural networks \\
\hline DBS & Dried blood spot \\
\hline FA & Formic acid \\
\hline FDR & False discovery rate \\
\hline GEE & Generalized estimating equation \\
\hline GLMM & Generalized linear mixed models \\
\hline GO & Gene ontology \\
\hline HDL & High density lipoprotein \\
\hline IL-10 & Interleukin-10 \\
\hline LASSO & Least absolute shrinkage and selection operation \\
\hline LDLR & Low density lipoprotein receptor \\
\hline LIMMA & Linear models for microarray data \\
\hline MAC & Membrane attack complex \\
\hline NanoLC-MS/MS & Nano-electrospray ionization liquid chromatography tandem mass spectrometry \\
\hline NFOR & Nonfunctional overreaching \\
\hline OTS & Overtraining syndrome \\
\hline PPI & Protein-protein interaction \\
\hline RAAM & Race Across America \\
\hline sPLSda & Sparse partial least squares discriminant analysis \\
\hline STAT3 & Signal transducer and activator of transcription 3 \\
\hline STRING & Search tool for the retrieval of interacting genes/proteins \\
\hline TDS & Training distress scale \\
\hline TNF- $\alpha$ & Tumor necrosis factor alpha \\
\hline UPLC & Ultraperformance liquid chromatography \\
\hline
\end{tabular}

\section{References}

1. Meeusen, R.; Duclos, M.; Foster, C.; Fry, A.; Gleeson, M.; Nieman, D.; Raglin, J.; Rietjens, G.; Steinacker, J.; Urhausen, A.; et al. Prevention, diagnosis, and treatment of the overtraining syndrome: Joint consensus statement of the European College of Sport Science and the American College of Sports Medicine. Med. Sci. Sports Exerc. 2013, 45, 186-205. [CrossRef] [PubMed]

2. Aubry, A.; Hausswirth, C.; Louis, J.; Coutts, A.J.; Le Meur, Y. Functional overreaching: The key to peak performance during the taper? Med. Sci. Sports Exerc. 2014, 46, 1769-1777. [CrossRef] [PubMed]

3. Soligard, T.; Schwellnus, M.; Alonso, J.M.; Bahr, R.; Clarsen, B.; Dijkstra, H.P.; Gabbett, T.; Gleeson, M.; Hägglund, M.; Hutchinson, M.R.; et al. How much is too much? (Part 1) International Olympic Committee consensus statement on load in sport and risk of injury. Br. J. Sports Med. 2016, 50, 1030-1041. [CrossRef] [PubMed]

4. Nieman, D.C.; Groen, A.J.; Pugachev, A.; Vacca, G. Detection of functional overreaching in endurance athletes using proteomics. Proteomes 2018, 6, 33. [CrossRef] [PubMed] 
5. Szklarczyk, D.; Morris, J.H.; Cook, H.; Kuhn, M.; Wyder, S.; Simonovic, M.; Santos, A.; Doncheva, N.T.; Roth, A.; Bork, P.; et al. The STRING database in 2017: Quality-controlled protein-protein association networks, made broadly accessible. Nucleic Acids Res. 2017, 45, D362-D368. [CrossRef] [PubMed]

6. Martin, N.J.; Bunch, J.; Cooper, H.J. Dried blood spot proteomics: Surface extraction of endogenous proteins coupled with automated sample preparation and mass spectrometry analysis. J. Am. Soc. Mass Spectrom. 2013, 24, 1242-1249. [CrossRef]

7. Merritt, E.K.; Nieman, D.C.; Toone, B.R.; Groen, A.; Pugachev, A. Proteomic markers of non-functional overreaching during the Race Across America (RAAM): A case study. Front. Physiol. 2019, 10, 1410. [CrossRef]

8. Kurgan, N.; Noaman, N.; Pergande, M.R.; Cologna, S.M.; Coorssen, J.R.; Klentrou, P. Changes to the human serum proteome in response to high intensity interval exercise: A sequential top-down proteomic analysis. Front. Physiol. 2019, 10, 362. [CrossRef]

9. Whitham, M.; Parker, B.L.; Friedrichsen, M.; Hingst, J.R.; Hjorth, M.; Hughes, W.E.; Egan, C.L.; Cron, L.; Watt, K.I.; Kuchel, R.P.; et al. Extracellular vesicles provide a means for tissue crosstalk during exercise. Cell Metab. 2018, 27, 237-251. [CrossRef]

10. Scoppetta, F.; Tartaglia, M.; Renzone, G.; Avellini, L.; Gaiti, A.; Scaloni, A.; Chiaradia, E. Plasma protein changes in horse after prolonged physical exercise: A proteomic study. J. Proteom. 2012, 75, 4494-4504. [CrossRef]

11. Hou, D.D.; Zhu, R.Z.; Sun, Z.; Ma, X.D.; Wang, D.C.; Timothy, H.; Chen, W.N.; Yan, F.; Lei, P.; Han, X.W.; et al. Serum proteomics analysis in rats of immunosuppression induced by chronic stress. Scand. J. Immunol. 2016, 84, 165-173. [CrossRef] [PubMed]

12. Guo, Y.; Li, E. Proteomics analysis of intensive exercise-induced disorders of gametogenesis in the testis using isobaric tags for relative and absolute quantification (iTRAQ) analysis. Reprod. Fertil. Dev. 2018, 30, 1785-1793. [CrossRef] [PubMed]

13. Balfoussia, E.; Skenderi, K.; Tsironi, M.; Balfoussia, E.; Skenderi, K.; Tsironi, M.; Anagnostopoulos, A.K.; Parthimos, N.; Vougas, K.; Papassotiriou, I.; et al. A proteomic study of plasma protein changes under extreme physical stress. J. Proteom. 2014, 98, 1-14. [CrossRef] [PubMed]

14. Cywinska, A.; Gorecka, R.; Szarska, E.; Witkowski, L.; Dziekan, P.; Schollenberger, A. Serum amyloid A level as a potential indicator of the status of endurance horses. Equine Vet. J. Suppl. 2010, 38, 23-27. [CrossRef]

15. Cywinska, A.; Witkowski, L.; Szarska, E.; Schollenberger, A.; Winnicka, A. Serum amyloid A (SAA) concentration after training sessions in Arabian race and endurance horses. BMC Vet. Res. 2013, 9, 91. [CrossRef]

16. Valle, E.; Zanatta, R.; Odetti, P.; Traverso, N.; Furfaro, A.; Bergero, D.; Badino, P.; Girardi, C.; Miniscalco, B.; Bergagna, S.; et al. Effects of competition on acute phase proteins and lymphocyte subpopulations-Oxidative stress markers in eventing horses. J. Anim. Physiol. Anim. Nutr. 2015, 99, 856-863. [CrossRef]

17. Casella, S.; Fazio, F.; Russo, C.; Giudice, E.; Piccione, G. Acute phase proteins response in hunting dogs. J. Vet. Diagn. Investig. 2013, 25, 577-580. [CrossRef]

18. Wakshlag, J.J.; Stokol, T.; Geske, S.M.; Greger, C.E.; Angle, C.T.; Gillette, R.L. Evaluation of exercise-induced changes in concentrations of $\mathrm{C}$-reactive protein and serum biochemical values in sled dogs completing a long-distance endurance race. Am. J. Vet. Res. 2010, 71, 1207-1213. [CrossRef]

19. Art, T.; Franck, T.; Gangl, M.; Votion, D.; Kohnen, S.; Deby-Dupont, G.; Serteyn, D. Plasma concentrations of myeloperoxidase in endurance and 3-day event horses after a competition. Equine Vet. J. Suppl. 2006, 36, 298-302. [CrossRef]

20. Serteyn, D.; Sandersen, C.; Lejeune, J.P.; de la Rebière de Pouyade, G.; Ceusters, J.; Mouithys-Mickalad, A.; Niesten, A.; Fraipont, A.; van Erck, E.; Goachet, A.G.; et al. Effect of a 120 km endurance race on plasma and muscular neutrophil elastase and myeloperoxidase concentrations in horses. Equine Vet. J. Suppl. 2010, 38, 275-279. [CrossRef]

21. Lejeune, J.P.; Sandersen, C.; Votion, D.; Caudron, I.; Vander Heyden, L.; Franck, T.; Ceusters, J.; Mouithys-Mickalad, A.; Niesten, A.; De La Rebière de Pouyade, G.; et al. Effect of intensive exercise on plasmatic neutrophil elastase level in eventing and endurance horses. Equine Vet. J. Suppl. 2010, 38, 12-16. [CrossRef] [PubMed] 
22. Grove, J.R.; Main, L.C.; Partridge, K.; Bishop, D.J.; Russell, S.; Shepherdson, A.; Ferguson, L. Training distress and performance readiness: Laboratory and field validation of a brief self-report measure. Scand. J. Med. Sci. Sports 2014, 24, e483-e490. [CrossRef] [PubMed]

23. Demichev, V.; Messner, C.B.; Vernardis, S.I.; Lilley, K.S.; Ralser, M. DIA-NN: Neural networks and interference correction enable deep proteome coverage in high throughput. Nat. Methods 2020, 17, 41-44. [CrossRef] [PubMed]

24. Ritchie, M.E.; Phipson, B.; Wu, D.; Hu, Y.; Law, C.W.; Shi, W.; Smyth, G.K. Limma powers differential expression analyses for RNA-sequencing and microarray studies. Nucleic Acids Res. 2015, 43, e47. [CrossRef]

25. Rohart, F.; Gautier, B.; Singh, A.; Lê Cao, K.A. MixOmics: An R package for 'omics feature selection and multiple data integration. PLoS Comput. Biol. 2017, 13, e1005752. [CrossRef]

26. Friedman, J.; Hastie, T.; Tibshirani, R. Regularization paths for generalized linear models via coordinate descent. J. Stat. Softw. 2010, 33, 1-22. [CrossRef]

27. Yao, X.; Gordon, E.M.; Figueroa, D.M.; Barochia, A.V.; Levine, S.J. Emerging roles of apolipoprotein E and apolipoprotein A-I in the pathogenesis and treatment of lung disease. Am. J. Respir. Cell Mol. Biol. 2016, 55, 159-169. [CrossRef]

28. Bach-Ngohou, K.; Nazih, H.; Nazih-Sanderson, F.; Zaïr, Y.; Le Carrer, D.; Krempf, M.; Bard, J.M. Negative and independent influence of apolipoprotein $\mathrm{E}$ on C-reactive protein (CRP) concentration in obese adults. Potential anti-inflammatory role of apoE in vivo. Int. J. Obes. Relat. Metab. Disord. 2001, 25, 1752-1758. [CrossRef]

29. Cunin, P.; Beauvillain, C.; Miot, C.; Augusto, J.F.; Preisser, L.; Blanchard, S.; Pignon, P.; Scotet, M.; Garo, E.; Fremaux, I.; et al. Clusterin facilitates apoptotic cell clearance and prevents apoptotic cell-induced autoimmune responses. Cell Death Dis. 2016, 7, e2215. [CrossRef]

30. Jenne, D.E.; Tschopp, J. Clusterin: The intriguing guises of a widely expressed glycoprotein. Trends Biochem. Sci. 1992, 17, 154-159. [CrossRef]

31. Lubbers, R.; van Essen, M.F.; van Kooten, C.; Trouw, L.A. Production of complement components by cells of the immune system. Clin. Exp. Immunol. 2017, 188, 183-194. [CrossRef] [PubMed]

32. Manthey, H.D.; Woodruff, T.M.; Taylor, S.M.; Monk, P.N. Complement component 5a (C5a). Int. J. Biochem. Cell Biol. 2009, 41, 2114-2117.33. [CrossRef] [PubMed]

33. Xu, S.; Venge, P. Lipocalins as biochemical markers of disease. Biochim. Biophys. Acta 2000, 1482, $298-307$. [CrossRef]

34. Zabetian-Targhi, F.; Mahmoudi, M.J.; Rezaei, N.; Mahmoudi, M. Retinol binding protein 4 in relation to diet, inflammation, immunity, and cardiovascular diseases. Adv. Nutr. 2015, 6, 748-762. [CrossRef]

35. Meyer, E.J.; Nenke, M.A.; Rankin, W.; Lewis, J.G.; Torpy, D.J. Corticosteroid-binding globulin: A review of basic and clinical advances. Horm. Metab. Res. 2016, 48, 359-371. [CrossRef]

36. Gardill, B.R.; Vogl, M.R.; Lin, H.Y.; Hammond, G.L.; Muller, Y.A. Corticosteroid-binding globulin: Structure-function implications from species differences. PLoS ONE 2012, 7, e52759. [CrossRef]

37. Chao, J.; Li, P.; Chao, L. Kallistatin: Double-edged role in angiogenesis, apoptosis and oxidative stress. Biol. Chem. 2017, 398, 1309-1317. [CrossRef]

38. Chao, J.; Guo, Y.; Chao, L. Protective role of endogenous kallistatin in vascular injury and senescence by inhibiting oxidative stress and inflammation. Oxid. Med. Cell Longev. 2018, 2018, 4138560. [CrossRef]

39. Wu, G.; Quek, A.J.; Caradoc-Davies, T.T.; Mazzitelli, B.; Whisstock, J.C.; Law, R.H.P. Structural studies of plasmin inhibition. Biochem. Soc. Trans. 2019, 47, 541-557. [CrossRef]

40. Cowland, J.B.; Borregaard, N. Granulopoiesis and granules of human neutrophils. Immunol. Rev. 2016, 273, 11-28. [CrossRef]

41. Yin, C.; Heit, B. Armed for destruction: Formation, function and trafficking of neutrophil granules. Cell Tissue Res. 2018, 371, 455-471. [CrossRef] [PubMed]

42. Schiopu, A.; Cotoi, O.S. S100A8 and S100A9: DAMPs at the crossroads between innate immunity, traditional risk factors, and cardiovascular disease. Mediators Inflamm. 2013, 2013, 828354. [CrossRef] [PubMed]

43. Wang, S.; Song, R.; Wang, Z.; Jing, Z.; Wang, S.; Ma, J. S100A8/A9 in inflammation. Front. Immunol. 2018, 9, 1298. [CrossRef] [PubMed]

44. Shirakawa, K.; Endo, J.; Kataoka, M.; Katsumata, Y.; Yoshida, N.; Yamamoto, T.; Isobe, S.; Moriyama, H.; Goto, S.; Kitakata, H.; et al. IL (Interleukin)-10-STAT3 galectin-3 axis is essential for osteopontin-producing reparative macrophage polarization after myocardial infarction. Circulation 2018, 138, 2021-2035. [CrossRef] 
45. MacKinnon, A.C.; Farnworth, S.L.; Hodkinson, P.S.; Henderson, N.C.; Atkinson, K.M.; Leffler, H.; Nilsson, U.J.; Haslett, C.; Forbes, S.J.; Sethi, T. Regulation of alternative macrophage activation by galectin-3. J. Immunol. 2008, 180, 2650-2658. [CrossRef]

46. Schwebach, C.L.; Agrawal, R.; Lindert, S.; Kudryashova, E.; Kudryashov, D.S. The roles of actin-binding domains 1 and 2 in the calcium-dependent regulation of actin filament bundling by human plastins. J. Mol. Biol. 2017, 429, 2490-2508. [CrossRef] [PubMed]

47. Hamey, J.J.; Wilkins, M.R. Methylation of elongation factor 1A: Where, who, and why? Trends Biochem. Sci. 2018, 43, 211-223. [CrossRef]

48. Wang, J.C.; Lee, J.Y.; Christian, S.; Dang-Lawson, M.; Pritchard, C.; Freeman, S.A.; Gold, M.R. The Rap1-cofilin-1 pathway coordinates actin reorganization and MTOC polarization at the B cell immune synapse. J. Cell Sci. 2017, 130, 1094-1109. [CrossRef]

49. Li, Y.; Jin, Y.; Liu, B.; Lu, D.; Zhu, M.; Jin, Y.; McNutt, M.A.; Yin, Y. PTEN $\alpha$ promotes neutrophil chemotaxis through regulation of cell deformability. Blood 2019, 133, 2079-2089. [CrossRef]

50. Matsumoto, M.; Hirata, T. Moesin regulates neutrophil rolling velocity in vivo. Cell Immunol. 2016, 304-305, 59-62. [CrossRef]

51. Feuk-Lagerstedt, E.; Samuelsson, M.; Mosgoeller, W.; Movitz, C.; Rosqvist, A.; Bergström, J.; Larsson, T.; Steiner, M.; Prohaska, R.; Karlsson, A. The presence of stomatin in detergent-insoluble domains of neutrophil granule membranes. J. Leukoc. Biol. 2002, 72, 970-977. [PubMed]

52. Geyer, P.E.; Holdt, L.M.; Teupser, D.; Mann, M. Revisiting biomarker discovery by plasma proteomics. Mol. Syst. Biol. 2017, 13, 942. [CrossRef] [PubMed]

(C) 2020 by the authors. Licensee MDPI, Basel, Switzerland. This article is an open access article distributed under the terms and conditions of the Creative Commons Attribution (CC BY) license (http://creativecommons.org/licenses/by/4.0/). 